DOI: $10.17707 /$ AgricultForest.61.4.12

\author{
Bosco BASHANGWA MPOZI, Edouard MUSABANGANJI, \\ Patrice NDIMANYA, Philippe LEBAILLY ${ }^{1}$
}

\title{
ANALYSIS OF THE ADOPTION OF PASSION FRUIT (PASSIFLORA EDULIS) IN FARMING SYSTEMS, MATONGO-BURUNDI
}

\begin{abstract}
SUMMARY
The commercial potential of passion fruit is expanding as demand for both fresh fruit and processed juice is increasing in Burundi. Due to the current situation with an unstable market of traditional crops for export, farmers in Matongo have embraced passion fruit as a new source of household income. As the crop generates substantial revenues for farmers, wholesalers and processors, it is important to sustain this sector. The purpose of this research was to compare four variants of diffusionist arguments (age, sex, household size and level of education) and their expression into adoption. Comparative descriptive statistical analysis between adopters and non-adopters to test the essential factors, and participatory survey methods for gathering information were used. Our results showed a highly significant difference between the category of adopters and nonadopters at $\mathrm{p}<0.01$. However, no significant difference was found between adopters and non-adopters within level of education. Data on the level of education demonstrated that those with little or no education adopted more passion fruit [illiterates (48.9\%) and primary level (45.9\%)] than these with secondary level (5.2\%). The heads of household adopters and non-adopters are mainly men at a rate of 83.7 and $88.3 \%$, and household size was not a discriminating factor. The factors that promote the adoption of passion fruit are high yield and continuous production, high market demand and permanent source of revenue. Defining only a few variables to analyse the adoption trend could mislead our findings. A participatory approach seems most appropriate for understanding adoption and non-adoption of innovation.
\end{abstract}

Keywords: passion fruit, innovation, adoption, determinants

\section{INTRODUCTION}

While the economies of the subregion are diversifying into other activities, the Burundian economy still relies on its agriculture and is essentially dominated by small family farms. In 2014, the contribution of agriculture to gross domestic product (GDP) ranged between 40 and $56 \%$. The sector's contribution to export

\footnotetext{
${ }^{1}$ Bosco Bashangwa Mpozi, (corresponding author: mpoziba@yahoo.fr; bmpozi@doct.ulg.ac.be), Edouard Musabanganji, Philippe Lebailly, Economy and Rural Development Unit, Gembloux Agro-Bio Tech - University of Liège, BELGIUM, Patrice Ndimanya, Faculties of Economics, Department of Rural Economy- University of Burundi, BURUNDI

Paper presented at the 6th International Scientific Agricultural Symposium "AGROSYM 2015"

Note: The authors declare that they have no conflicts of interest. Authorship Form signed online.
} 
earnings was estimated to be $86 \%$ in the same year (MINAGRIE, 2014). However, the performance of this sector remains low and per capita agricultural production continues to fall, affecting the survival of rural households due to the decrease in revenues and accentuating the lack of food at household level. Despite the weak performance, Burundian agriculture has already proven that it possesses capabilities to overcome major farming system constraints and sociopolitical and economic crises (Cochet, 2001; Bourgerie et al., 1995). Therefore, agriculture remains at the centre of solutions to the growing food insecurity. These innovations can be seen in Matongo municipality, with the development of a farming system based on passion fruit that allows involved farmers to cope with the agricultural crisis in the country and thereby ensure the welfare of households.

Passion fruit can generate substantial income for farmers as well as traders, collectors and small agribusinesses. Households adopting this crop have made choices based on their perceptions and constraints in their activities (Roussy et al., 2015)-).

This article, therefore, aims to identify the determinants of the adoption of passion fruit in order to understand the choices of households and the contribution of this crop to food security and poverty reduction in these households.

\section{MATERIAL AND METHODS}

The municipality of Matongo is located in the south-west of the province of Kayanza. It has an estimated area of $167.80 \mathrm{~km}^{2}$ equivalent to $13.6 \%$ of the province area $\left(1,233.24 \mathrm{~km}^{2}\right)$ and $0.6 \%$ of the country $\left(27,834 \mathrm{~km}^{2}\right)$. It is divided into four administrative zones and 35 subzones. It covers two natural regions, namely Mugamba and Buyenzi. In the last ten years, the precipitations averaged $1,374.2 \mathrm{~mm}$ and the average temperature was $18.2{ }^{\circ} \mathrm{C}$ for the same period. The hottest year was the year 2003 with $20.3^{\circ} \mathrm{C}$ and the coldest was 2008 with 17.1 ${ }^{\circ} \mathrm{C}$ (MPDR, 2006).

The study was carried out through surveys conducted on a sample of 135 farmers who cultivate passion fruit. A series of semi-structured interviews and interviews was conducted with farmers during the season B of 2010 (February 16 to June 15). The interviews started at their respective homes and then in their firms and this allowed to collect socio-demographic data from the respondents. The second phase of the study was conducted in season B of 2012 and consisted in interviewing 60 householders among the 135 selected farmers by comparing them to a control group of 60 farmers who are not involved in the passion fruit cultivation. This phase helped in determining the contribution of income earned from passion fruit in the livelihoods of these households. Non-probability sampling was used due to the lack of data related to households involved in this activity.

Most mathematical models use variables to explain the adoption of a given innovation. In the framework of this study, observable determinants selected in 
this study correspond to the characteristics of the farmer and his farm. These are age, educational level, gender and household size. Based on these variables, the following assumptions were made:

H1: Age - Age is a discriminating factor regarding the adoption of passion fruit (Feder, 1982). Young people adopt an innovation more easily than older people, who are mostly at risk.

H2: Level of education - The level of education affects the appreciation of innovations and is thus a discriminating variable (Rahm and Singh, 1988).

H3: Size of the household - Household size is often mentioned as a key variable in the adoption of new technologies (Kebede et al., 1990).

H4: Gender - Men have more access to information and inputs than women (Dey, 1981), and thus gender is a discriminating variable.

Alongside these observable determinants, unobservable determinants will also be studied through studies of the perceptions of adoption (Menapace et al., 2013) based on stated preference methods (Birol et al., 2006) through surveys. This work proposed testing the assumptions stated above by comparing them to the results from the descriptive analysis appearing in the results obtained from the descriptive statistical analysis of the surveyed households. It also evaluates, through an economic analysis, the reasons behind the adoption of the passion fruit crop. Due to lack of literature related to this crop in Burundi and especially in the study area, for the variable income, we solely based our computation on the farmers' responses regardless their reliability as most of them were illiterate.

\section{RESULTS AND DISCUSSION}

The results show that heads of household adopters are characterized by a relatively young age with an average of 35.7 years against 46.6 years for nonadopters (Table 1). Age is a discriminating factor in the adoption of passion fruit ( $p<0.001)$. These results corroborate those of Anderson et al. (2005) who consider age as a factor that reduces adoption. Abdulai and Huffam (2005), meanwhile, find that older farmers have a more limited vision of things that does not push them to change their practices. In contrast, young farmers are subject to very strong social constraints that force them to explore new sources of revenue.

With regard to the level of study, some authors show that it promotes the adoption of innovations (Barham et al., 2004; Sauer and Zilberman, 2009). Our results show that $48.7 \%$ of illiterate respondents adopted innovations compared to $35 \%$ of non-adopters, followed by $45.9 \%$ of those with primary education against $55 \%$ of non-adopters. Only $6.7 \%$ of adopters have a high school education against $10 \%$ of non-adopters (Table 2). The level of education is therefore not a discriminating variable $(\mathrm{p}=0.139)$, corroborating the results of Knowler and Bradshaw (2007), which show that there is no significant relationship between the level of study and adoption. Clay et al. (1998) also show that education is a non-significant factor. However, the level of education is a determining variable in improving agricultural productivity. Lau et al. (1991) found that a $10 \%$ increase in the educational level of the workforce generated 
0.3\% economic growth in sub-Saharan Africa, 1.7\% in Latin America and 1.3\% in East Asia. However, having a low education level does not challenge the ingenuity of farmers in terms of their ability to find solutions for their survival. Several authors show that farmers' practices make research efforts more effective (Akinnifesi et al., 2009).

Table 1 : Distribution of farmers surveyed by age classes

\begin{tabular}{ccccccc}
\hline Age & Adopters & \multicolumn{2}{c}{ Non-Adopters } & \multicolumn{2}{c}{ Total } \\
\hline & Effectives & $\%$ & Effectif & $\%$ & Effectif & $\%$ \\
\hline$<18$ & 1 & 0.7 & 0 & 0 & 1 & 0.5 \\
$18-30$ & 63 & 46.7 & 6 & 10 & 69 & 35.4 \\
$31-40$ & 34 & 25.2 & 15 & 25 & 49 & 25.1 \\
$41-50$ & 18 & 13.3 & 21 & 35 & 39 & 20 \\
$>50$ & 19 & 14.1 & 18 & 30 & 37 & 19 \\
Total & 135 & 100 & 60 & 100 & 195 & 100 \\
\hline Middle & $35.7 \pm 13.7$ & & $46.6 \pm 12.7$ \\
age & & \multicolumn{7}{c}{} \\
\hline
\end{tabular}

Table 2: Distribution of farmers surveyed by level of education

\begin{tabular}{lcccccc}
\hline Level of education & \multicolumn{2}{c}{ Adopters } & \multicolumn{2}{c}{ Non-Adopters } & \multicolumn{2}{c}{ Total } \\
\hline & Effectives & $\%$ & Effectives & $\%$ & Effectives & $\%$ \\
\hline Illiterate & 66 & 48.9 & 21 & 35 & 87 & 44.6 \\
Primary education & 62 & 45.9 & 33 & 55 & 95 & 48.7 \\
$\begin{array}{l}\text { Secondary } \\
\text { education }\end{array}$ & 7 & 5.2 & 6 & 10 & 13 & 6.7 \\
Total & 135 & 100 & 60 & 100 & 195 & 100 \\
\hline
\end{tabular}

The results show that household heads are mainly men, with $83.7 \%$ among the adopters of passion fruit crop and $88.3 \%$ among non-adopters. Doss and Morris (2001) consider gender to be a discriminatory factor in accessing technology, but this is not the case in the study area because there is no difference between adopters and non-adopters regarding the gender variable. However, Nyanjong' and Lagat (2012) explain that the low representation of women can be explained by the problem of access to land, education, etc., and an experienced past in rural areas.

As for the size of the households, there is no significant difference between household size among adopters and non-adopters (4.5 persons per household on average; $p=0.792$ ) (Table 3 ). Analysis of agricultural assets shows that there is an average of two active people per household among adopters and non-adopters (Table 4). This number seems insufficient when we know that farmers in Matongo still use their traditional means (hoe) for agriculture-related activities 
and have scattered plots in the villages. This invalidates the hypothesis of Kebede et al. (1990), who consider the number of household members as a source of labour and therefore as a variable related positively to the adoption of a new crop demanding an intensive agricultural workforce. However, Akinola and Young (1985) argue that, on the one hand, family size often influences the behaviour of farmers in adopting new technologies, and on the other hand, it prevents the adoption of certain new technologies such as animal traction (in the case of a large family size), and secondly it requires householders to increase revenues as an active household member has to work to support at least two inactive persons in the household.

Table 3 : Household size

\begin{tabular}{ccccc}
\hline Household size & \multicolumn{2}{c}{ Adopters } & \multicolumn{2}{c}{ Non-Adopters } \\
\hline$[1-3]$ & Effectives & $\%$ & Effectives & $\%$ \\
\hline $4-6]$ & 46 & 34.1 & 19 & 31.7 \\
{$[7-9]$} & 63 & 46.7 & 31 & 51.7 \\
$\geq 10$ & 24 & 17.8 & 10 & 16.7 \\
Total & 2 & 1.5 & 0 & 0 \\
Middle & 135 & 100 & 60 & 100 \\
\hline
\end{tabular}

Table 4: Active household

\begin{tabular}{ccccc}
\hline Active household & Adopters & \multicolumn{2}{c}{ Non-Adopters } \\
\hline & Effectives & $\%$ & Effectives & $\%$ \\
\hline$[1-2]$ & 111 & 82.2 & 43 & 71.7 \\
{$[3-4]$} & 21 & 15.6 & 15 & 25 \\
$>4$ & 3 & 2.2 & 2 & 3.3 \\
Total & 135 & 100 & 60 & 100 \\
\hline Middle & 2.1 & & 2.2 & \\
\hline
\end{tabular}

The results show that various reasons have led farmers to adopt the passion fruit crop. All farmers say that they have adopted the crop in response to the market demand and income from it, this being 60\% to diversify their source of income, $75 \%$ for its performance and $80 \%$ for food security (Table 5).

Diversification minimizes the risks of losing source of income and also helps ensure household food security. The performance analysis shows that passion fruit has a better yield than other crops grown in Matongo. Passion fruit has an average yield of 10.7 tonnes/ha in the agro-ecological conditions of 
Matongo, followed by sweet potatoes, Irish potatoes, , green peas, beans and corn with respectively 9.7, 4.5, , 2.8, 0.8 and 0.7 tonnes/ha.

However, good performance does not mean a good income. The analysis of income from passion fruit shows that it contributes significantly to household incomes and produces a significant reduction in poverty. A proportion of $80 \%$ of adopters live above the estimated poverty line, according to MINITER (2011), at 135.9 US \$ (191,348 Fbu) per year. This means that passion fruit greatly reduces poverty in the adopters' households. But that does not mean that farms can grow and perpetuate themselves in time. The analysis of the reproduction threshold estimated by FSMS (2012) at 213.1 US \$ (300,000 Fbu) shows that 36,7 \% of adopters are below the line, which means that their operations are doomed to disappear one day. With regard to food security and social well-being, Bashangwa et al. (2015) state that only $40 \%$ of adopters' households have the necessary minimum income to meet the food needs of a rural family household in Burundi, evaluated at 360,3 US \$ (507,350 Fbu) per year according to Zoyem et al. (2008).

Table 4 : Reasons for adoption of passion fruit from households surveyed adopters

\begin{tabular}{ll}
\hline Reasons for adoption & Percent \\
\hline Efficiency & 75 \\
Income & 100 \\
Income diversification & 60 \\
Market demand & 100 \\
Food security & 80 \\
\hline
\end{tabular}

\section{CONCLUSIONS}

The study reveals that even in the context of endogenous innovation, the decision-making process on the adoption of a new crop is the result of observable and unobservable factors that impact on agricultural household living conditions. The study analysed both observable and unobservable determinants that allowed farmers to adopt passion fruit. With regard to the observable determinants, the results show that age favours the adoption of passion fruit while the level of education does not have a positive influence on the adoption of the passion fruit crop. This shows the ingenuity of Matongo farmers, who can innovate in the absence of any external support in order to maintain their operations and improve their living conditions. Gender does not influence the adoption of passion fruit but shows an improvement in the ownership of women in rural areas, especially in Matongo because the majority of women in charge of passion fruit farms were married. Household size does not influence the adoption of passion fruit but does encourage householders to adopt or not a high-performance culture and strong added value to support at least two inactive individuals in households. Alongside these observable determinants, the study highlighted the unobservable 
determinants focusing on declared preferences by farmers. However, the evaluation in monetary value showed that there is great heterogeneity in terms of monetary income among adopters and that income does not allow all households to improve their living conditions. This demonstrates the need for a diversification of income sources in this cropping system based on passion fruit if farmers want to improve their living conditions and maintain the sustainability of their farming operations.

\section{REFERENCES}

Abdulai, A., Huffman, W.E. (2005). The diffusion of new agricultural technologies: The case of crossbred-cow technology in Tanzania. American Journal of Agricultural Economics, 87(3): 645-659.

Akinnifesi F.K., Sileshi G., Mngomba S.A., Mhango J., Mkonda A., Chilanga T., Ajayi O.C., Dhliwayo P. et Betserai I., 2009. Ethnoecological knowledge in the selection of elite cultivars of Uapaca kirkiana in southern Africa. World Congress of Agroforestry 2009, Book of Abstracts, Technical session no 27: The role of underutilized crops for agroforestry. Nairobi, Kenya, 27 août 2009.

Anderson, J. B., D. A. Jolly and R. D. Green (2005). Determinants of farmer adoption of organic production methods in the fresh-market produce sector in California: A logistic regression analysis. 2005 Annual Meeting, July 6-8, 2005, San Francisco, California, Western Agricultural Economics Association.

Barham, B. L., J. D. Foltz, D. Jackson-Smith and S. Moon (2004). "The dynamics of agricultural biotechnology adoption: Lessons from series rBST use in Wisconsin, 1994-2001." American Journal of Agricultural Economics 86(1): 61-72.

Bashangwa M., Ndimanya P., Lebailly P., 2015. Fruit de la passion, culture négligée au Burundi. Peut-elle contribuer à réduire la pauvreté des ménages adoptants ? Etude de cas des ménages de la Commune Matongo. Communication au colloque XXXème journée du développement ATM 2015. Le bilan des objectifs du millénaire pour le développement 15 ans après : réduction de la pauvreté et/ou monté des inégalités ? Université de Rouen. [Bashangwa M., Ndimanya P., Lebailly P., 2015. Passion fruit, neglected crop in Burundi. Can the crop contribute in poverty reduction among households of adopters? A case study of households in the commune Matongo municipality. A presentation at the $30^{\text {th }}$ Development Day Symposium ATM 2015: "The Progress of Millennium Development Goals after 15 years: poverty reduction and / or inequality increase?" University of Rouen, France].

Birol, E., Karousakis, K., Koundouri, P. (2006). Using a choice experiment to account for preference heterogeneity in wetland attributes: The case of Cheimaditida wetland in Greece. Ecological Economics, 60(1): 145-156.

Bourgerie J, Lecompte D. et Martin S., 1995 : Economie burundaise : adaptation à la crise politique, note CFD, Bujumbura.[Bourgerie J, Lecompte D. et Martin S., 1995. Burundi Economy: adaptating to the political crisis, CFD notes, Bujumbura].

Clay, D., Reardon, T. \& Kangasniemi, J. 1998. Sustainable intensification in the highland tropics: Rwandan farmers' investments in land conservation and soil fertility. Economic Development and Cultural Change.

Cochet H., (2001). Crises et révolutions agricoles au Burundi. Paris, KARTHALA Editions, p. 468.

Dey, J., 1981. Gambian Women: unequal partners in rice developpement projects. J. Dev. Stud. 17 (3): 143-151. 
Falusi, A.O., 1975. "Application of Multi-variate Probit To Fertilizer Use Decision: Sample Survey of farmers in Three States in Nigeria". In: J. Rural Econ. Développement, Vol.9 N¹ PP.49-66.

Feder, G., 1982. Adoption of interrelated agricultural innovations: complementary and the risk, scale and credit. American Journal of Agricultural Economics pp 94-101.

FSMS, 2012. Burundi. Système de suivi de la sécurité alimentaire. Programme alimentaire mondial (PAM), Bujumbura, Burundi.[FSMS, 2012. Burundi. Food security monitoring system. World Food Programme (WFP), Bujumbura].

Kebede, Y., K. Gunjal and G. Coffin (1990), "Adoption of New technologies in Ethiopian Agriculture: The Case of Tegulet-Bulga District, Shoa Province." Agricultural Economics, 4, pp. 27 - 43.

Knowler, D. and B. Bradshaw (2007). "Farmers' adoption of conservation agriculture: A review and synthesis of recent research." Food Policy 32(1): 25-48.

Lau L. J., Jamison D. T. \& Louat F.F., 1991. Education and productivity in developing countries: an aggregate production function approach. The World Bank, Washington, USA.

Menapace, L., Colson, G., Raffaelli, R. (2013). Risk Aversion, Subjective Beliefs, and Farmer Risk Management Strategies. American Journal of Agricultural Economics, 95(2): 384-389.

Minagrie, 2014. Etats généraux de l'agriculture et de l'élevage. Rapport sur l'évaluation de la mise en œuvre des politiques agricoles nationales : défis et perspectives d'avenir. Bujumbura, p.158.[MINAGRIE, 2014. General Overview of Agriculture and Livestock. Report on the evaluation of the implementation of national agricultural policies: challenges and prospects. Bujumbura, p.158]

Mininter, 2011. Recensement général de la population et de l'habitat du Burundi en 2008. Tom 7 : caractéristiques des ménages et des habitations, Bujumbura, $60 \mathrm{p}$.

MPDR (Ministère de la planification et de la reconstruction, 2006. Monographie de la commune de Matongo. Programme d'appui à la gouvernance, PNUD, Burundi, p. 94

Nyanjong ' O.J. et Lagat J., 2012. Analysis of efficiency in sugarcane production: the case of men and women headed households in SONY sugar out -grower zone, Rongo and Trans-Mara districts, Kenya. MPRA Paper No. 40796,

Paridaens, A.-M., Belotti, L., Regi, S., Mahwane, J., Zoyem, J.-P., 2012. Analyse des données secondaires de la sécurité alimentaire, vulnérabilité et nutrition au Burundi, Bujumbura, Programme alimentaire mondial (PAM), p. 93.

Rahm, T. and R. D. Singh, 1988. Farm households in rural Burkina Faso: some evidence on allocative and direct returns to schooling, and male-female labor productivity differentials. World Development 16(3), 419-424

Roussy C., Ridier A., Chaib K., 2015. Adoption d'innovation par les agriculteurs : rôle des perceptions et des préférences. Working Paper SMART-LERECO N¹5-03.

Sauer, J. and D. Zilberman (2009). Innovation behaviour at farm level-Selection and identification. 49th annual meeting of the German Association of Agricultural Economics and Sociology, GEWISOLA, Kiel.

Warriner, G.K. \& Moul, T.M. 1992. Kinship and personal communication network influences on the adoption of agriculture conservation technology. Journal of Rural Studies, 8(3): 279-291.

Zoyem J.-P., Diang'a E. \& Wodon Q., 2008. Mesures et déterminants de l'insécurité alimentaire au Burundi selon l'approche de l'apport calorifique. Le journal statistique africain, 6: 35-66.[ Zoyem J.-P., Diang'a E. \& Wodon Q., 2008. Measures and Determinants of food insecurity in Burundi following the calorie intake approach. African Statistical Journal 6: 35-66.] 